\section{HAECKEL ON INFUSORIA}

$\mathrm{T}$ this communication* Prof. Haeckel discusses the different views which have been entertained as to the structure of the Infusoria, and adopts that of Prof. Siebold, that they are unicellular. This constitutes in his opinion a fundamental distinction betweent hem and the rest of the animal kingdom, although, strictly speaking, some species, as for instance, Loxodes rostrum, and Enchelys gigas, have more than one nucleus, and must, therefore, be regarded as physiologically consisting of more than one cell. Prof. Haeckel, however, does not attach much importance to these exceptional cases, because the multiplication of the nuclei involves little change of organisation in other respects.

The difficulty of conceiving a single cell with such complex properties becomes lessened, if we remember the nerve-cells of the higher animals, the thread-cells of many Acalephæ.

Considering, then, that the true Infusoria are unicellular, as first maintained by Prof. Siebold in 1845 , Prof. Haeckel denies that they have any near connection with either Cœlenterata or the worms. In all the higher groups of the animal kingdom the organism is multicellular, and develops itself from the original egg-cell by the characteristic process of segmentation, and the cellular mass thus formed differentiates itself into two epithelial layers, from the inner one of which the digestive canal, with all its appendages, develops itself; while from the outer layer are formed the skin, nervous system, \&c. In his monograph of the Calcareous Sponges, Prof. Haeckel has developed his views of the relations of these two primary layers in the principal groups of animals, and from this fundamental homology has enunciated the theory of a common original form, which he proposed to call "Gastraea," and from which all the higher forms of animals are derived. This theory, which he calls the Gastræa theory, is based upon the consideration that all the six higher animal classes, from the sponges to the lowest vertebrates, pass through a similar stage of development, which he proposes to call the Gastrula stage, and which he considers to be the most important and instructive embryonal form of the animal kingdom. In the calcareous sponges, for instance, this Gastrula law forms a simple generally egg-shaped body, surrounding an ample hollow, the primitive stomach, or digestive cavity, and with an orifice at one end, the primitive mouth. The wall of the digestive cavity consists of two layers, the entoderm, and the ectoderm, which, as Prof. Huxley was the first to point out, are homologous with the outer and inner layers of the vertebrate embryo. Similar larvæ occur in other sponges, and in many zoophytes, while as examples of embryonal forms in cther groups he refers to the researches of Kowalevsky in Phoronis, Sagitta, Euaxes, 'Ascidia, \&c. ; and of Ray Lankester in Mollusca. He considers that the larval forms of Arthropods can be reduced to the same type; and finally that the researches of Kowalevsky have shown that the same is the case with the lowest vertebrata (Amphioxus). The Infusoria, on the contrary, have no yolk-segmentation, no blastoderm, and consequently nothing which corresponds to the Gastrula stage, nor any homologue of the digestive cavity of other animals. The resemblance of many ciliated larvæ to the Infusoria is therefore merely superficial, the latter being unicellular, the latter multicellular. He regards this difference as so fundamental that he proposes to divide the animal kingdom into two great groups, the Protozoa, and the Metazoa, Blastozoa, or Gastrozoa. The Metazoa, to use his first name, he again divides into two; the Zoopkytes, or Cœlenterata on one side, and the Worms, from which again the Molluscs, Echinoderms, Arthropods, and Vertebrates have sprung, on the other.

* Zur Morphologie der Infusorien. Sep. Abdruck aus der Jenaischen Zeitscrift. Bd, vii.

\section{A LECTURE EXPERIMENT}

THE ordinary experiment described in books for demonstrating the heating of a body of fluid by convection currents consists in throwing bran into a vessel of water, to the bottom of which a source of heat is afterwards applied. Mr. Clowes's experiment, given in NATURE, vol. ix. p. 162, is no doubt more effective. I have, however, found that the ordinary experiment admits of being made quite satisfactory for the purpose of clear demonstration, and the hint may be useful to those to whom it has not already occurred.

Take a large beaker filled with water, and introduce down to the bottom the end of a burette filled with a strong indigo solution and closed at the top by the finger. If necessary, the solution may be driven out by the application of the mouth to the other end, and gently blowing. The burette must be carefully withdrawn without producing upward currents; this can be easily managed with a little care. The dark fluid now lies at the bottom of the clear water, with which, during a time sufficient

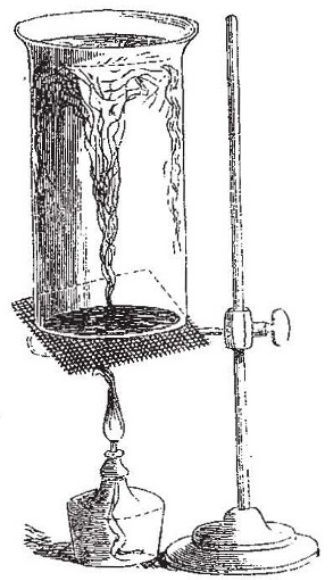

for the experiment, it does not appreciably mix. But when a spirit lamp is applied it rises in slender streams, which can be rendered very visible by placing a sheet of white paper behind the beaker. W. T. T. D.

\section{A SCIENCE LECTURE AT THE CHARTER- HOUSE}

A LECTURE on one who was once a Brother of the A Charterhouse, and who laid the foundations of scientific electricity, could not fail to be of interest when delivered within the walls of that building, where indeed many of the experiments of the original investigator in question were conducted. This pleasant duty devolved on Dr. Richardson on Thursday, January 22, when he gave to the brethren of the Charterhouse, and to many eminent friends, an experimental demonstration of the work of the early electrician, Stephen Gray.

The lecturer opened his discourse with an exposition of the personal history of $\mathrm{Mr}$. Gray ; of this, he said, he could gather little. He discovered Gray first at Canterbury, in 1692, making an observation of a mock sun, in the afternoon of February 6 . At this time Gray was evidently engaged on physical and astronomical research. In 1696 he was busy constructing a water microscope; in $\mathbf{5} 698$ he was engaged making a microscope with a micrometer for measuring the height of mercury in the barometer more exactly; in 1699, on April 7 , between 4 P.M. and 5 P.M., he was observing an unusual parhelion and a halo; in I 7or he was studying the fossils of Reculver 